\title{
The Students' Motivation in Writing through Mind Mapping at Tomakaka University of Mamuju
}

\section{Nurul Hasanah; Syahban Mada Ali}

\author{
${ }^{1}$ (English Education Department, Universitas Tomakaka, Indonesia) \\ ${ }^{2}$ (English Education Department, Universitas Tomakaka, Indonesia)
}

* Corresponding Author. E-mail: ${ }^{1}$ nurul.hasanah1@gmail.com\& ${ }^{2}$ syahban.syan@gmail.com

\begin{tabular}{|l|l|l|}
\hline Receive: $12 / 10 / 2020$ & Accepted: $19 / 10 / 2020$ & Published: 12/12/2020
\end{tabular}

\begin{abstract}
Abstrak
Penelitian ini bertujuan untuk mengetahui apakah penggunaan Mind Mapping dapat membantu memotivasi siswa dalam menulis. Penelitian ini menggunakan metode gabungan (mix method) dengan subjek penelitian adalah mahasiswa semester dua Universitas Tomakaka Mamuju. Data dikumpulkan dan dianalisis dengan scoring scale yang termaksud di dalamnya yaitu content, organization, vocabulary, language use, dan mechanic yang berdasarkan pada rubric Jacob. Selanjutnya, angket dan wawancara digunakan untuk mengetahui apakah mahasiswa termotivasi atau tidak. Angket tersebut dianalisis menggunakan Likert scale yang dibagi dalam beberapa kategori yaitu: strongly motivated, motivated, fairly motivated, unmotivated, and strongly unmotivated. Sedangkan wawancara digunakan untuk mengkonfirmasi jawaban mahasiswa terhadap angket yang telah terjawab. Hasil penelitian menunjukkan bahwa Mahasiswa semester 2 Universitas Tomakaka Mamuju termotivasi dalam belajar menulis melalui Mind Mapping. Hal ini dapat dibuktikan melalui data skor menulis mahasiswa, angket dan hasil wawanara. Hasil dari perlakuan yang diberikan kepada mahasiswa menggambarkan tren peningkatan nilai menulismereka. Selain itu, mahasiswa juga memberikan respon positif terhadap angket yang telah diberikan dimana pada umumnya mereka berpendapat bahwa Mind Mapping sangat bermanfaat dalam meningkatkan motivasi mereka dalam menulis.
\end{abstract}

Kata Kunci: Mind Mapping, TulisanMahasiswa, danMotivasiMahasiswa

\begin{abstract}
The aim of this research is to find out whether the use of mind mapping can motivate the students in writing. The method was used is mix method (Quantitative and Qualitative). The subject of this research was the second semester students of Tomakaka University of Mamuju. The data was collected and analyzed through scoring scale which includes the content, organization, vocabulary, language use and mechanics by using Jacob's scoring rubric. Then, to find out the students are motivated through the method applied or not, it was used questionnaire and interview. The questionnaire wasanalyzed by the Likert scale, it is divided into strongly motivated, motivated, fairly motivated, unmotivated, and strongly unmotivated.Then, interview are used to confirm the students
\end{abstract}


answers in the questionnaire. The result of this research is the second semester students of TomakakaUniversity of Mamuju are motivated in writing through Mind Mapping method. It can be shown from the data of writing test, questionnaire and interview. The result of the treatment given showed a trend of increasing students' writing score. And also, students gave positive responses to the questionnaire distributed where most students answered that Mind Mapping method was very useful in increasing their writing motivation.

Keywords:Mind Mapping, Students' Writing, and Students' Motivation.

\section{Introduction}

English is one of the subjects taught in school, since junior until senior high school. English language is also familiar as a skill. This skill is divided into two parts, productive skills and receptive skills. Productive skills are speaking and writing while receptive skills are listening and reading. In conjunction with that the researcher focuses this research on writing as one skill in English.

In university, writing is one the students' basic needs. Every students must be able to write well, they can at least convey what is on their minds in written form. Not only will help them complete the final project in the form of writing thesis, but they are further expected to develop their ideas through writing that can be read and put to good use by the community. However, what is discovered by lecturers every year when teaching writing to new students is still far from expectation. Students sometimes made mistake to complete their writing task with simple reason such as lack of vocabulary, not having enough ideas, could not complete the mechanic, and could not use connector well. These might occur since they had not enough writing experience and focused their attention mainly on grammar and vocabulary.

Another problem faced by the lecturers in writing class is the students' lack of enthusiasm in writing. They looked bored and sleepy in learning process. This phenomenon could be caused by many factors, such as the students have not enough motivation to follow the course and material, or the technique which provided is not suitable for the students.

These problems must be overcome early in their first year, as writing subject continues for the next few semesters. Improving from the start in an attempt to make the foundation of students' writing knowledge solid to face their future demands as the university students. Therefore, the lecturers have to be more creative in choosing the materials and teaching technique which can increase the students' writing ability and are able to make the writing class more interesting, motivating, exciting and effective. Various techniques or strategies of teaching writing can be applied by lecturers and one of them is Mind Mapping.

Al Kamli (2018: 70) found that mind mapping has a significant positive effect on the students' writing achievement as well as their attitudes towards writing in English. Conclusions of this particular study emphasize the usefulness of integrating grammatical clues along with syntactical associations within the mind maps, to help low-level learners apply grammatical rules while writing.

By considering the problem, the researcher is interested to conduct a research under the title: The Students' Motivation in Writing through Mind Mapping at Tomakaka University of Mamuju.

\section{Method}

This research will be mix methods (quantitative and qualitative). The 
instrument used to collect the data will be writing test, questionnaire, and interview. The tests will consist of pretest and posttest made by the researcher. The theme will be about "The Advantages and Disadvantages of Mobile Phone". Students will write in a paragraph then this will be measured by using Jacobs' scoring rubric. After that, the students are given questionnaire to know their motivation on English writing and some of them will be interviewed. The subject of this research will be the junior students of Tomakaka University of Mamuju, they are will be in the second semester of English study program of Teacher Training and Education.

\section{Findings and Discussions}

\section{Findings}

\section{a. The Analyzing of Students' Writing Score}

Table 1. The Rate Percentage and Frequency of Students' Score Pre-Test and Post-Test

\begin{tabular}{cccccc}
\hline Classification & Score & \multicolumn{2}{c}{ Pre-Test } & \multicolumn{2}{c}{ Post-Test } \\
\cline { 3 - 6 } & & $\mathrm{F}$ & $\%$ & $\mathrm{~F}$ & $\%$ \\
\hline Excellent & $96-100$ & 0 & 0 & 0 & 0 \\
Very good & $86-95$ & 0 & 0 & 5 & 16.7 \\
Good & $76-85$ & 1 & 3.3 & 23 & 76.7 \\
Fairly Good & $66-75$ & 15 & 50 & 2 & 6.6 \\
Fair & $56-65$ & 14 & 46.7 & 0 & 0 \\
Poor & $46-55$ & 0 & 0 & 0 & 0 \\
Very poor & $0-36$ & 0 & 0 & 0 & 0 \\
\hline Total & & 30 & 100 & 30 & 100 \\
\hline
\end{tabular}

The data shown in table 1 , the result of the pre-test is none $(0 \%)$ of students got excellent criterion. Then, 1 (3.3\%) students got good, 15 students (50\%) categorized fairly good and $14(46.7 \%)$ who reached fair. The result of the students' score in post-test have been changed. There was 5 $(16.7 \%)$ students who got very good, followed by $23(76.7 \%)$ was good and 2 $(6.6 \%)$ students got fairly good.
Table 2 The Mean Score between Pre-Test and Post-Test of Five Components of Writing

\begin{tabular}{lccc}
\hline \multirow{2}{*}{$\begin{array}{c}\text { Components of } \\
\text { Writing }\end{array}$} & \multicolumn{2}{c}{ Mean score } & \\
\cline { 2 - 3 } & $\begin{array}{c}\text { Pre- } \\
\text { Test }\end{array}$ & $\begin{array}{c}\text { Post- } \\
\text { Test }\end{array}$ & \\
\hline Content & 20.57 & 24.47 & 3.9 \\
Organization & 14.80 & 17.13 & 2.33 \\
Vocabulary & 14.77 & 17.00 & 2.23 \\
Language use & 14.30 & 18.60 & 4.3 \\
Mechanic & 2.07 & 3.07 & 1 \\
\hline \multicolumn{1}{c}{ Total } & 66.50 & 80.27 & 13.77 \\
\hline
\end{tabular}

The data in Table 2 showed that the mean score of five components of writing in pre-test and post-test were different in range 13.77 points. The mean score of pretest was 66.50 while the post-test was 80.27. It means that the mean score of posttest was higher than the pre-test. It can be concluded that all of the components of writing in post-test were higher than pretest. In content, the improvement was 3.9, while organization and vocabulary had the same arising were more than 2 point then followed by language use and mechanic 4.3 and 1 point continued. So, there was significant difference between pre-test and post-test.

\section{b. The Analyzing of Students' Motivation}

Questionnaire is one of the popular medium for collecting data in education and social research. The distribution of questionnaire in this research aims to find out whether the students are motivated in writing by using Mind Mapping. The questionnaire was distributed to the students after the treatment. In this research the questionnaire included 20 items which were expected to find out the motivation of the students in writing by using Mind Mapping. 
The questionnaire was responded by the students individually, it referred to the students' opinion after the treatment using Mind Mapping. The motivations of second semester students of Tomakaka University in writing by using Mind Mapping showed a great positive response. The data analysis can be seen in the following table.

Table 3 The Rate Percentage of the Students' Motivation

\begin{tabular}{cccc}
\hline Classification & $\begin{array}{c}\text { Rang } \\
\text { Score }\end{array}$ & F & $\begin{array}{c}\text { Percent } \\
\text { age }\end{array}$ \\
\hline Strongly motivated & $85-100$ & 13 & 43.3 \\
Motivated & $69-84$ & 17 & 56.7 \\
Fairly Motivated & $52-68$ & 0 & 0 \\
Unmotivated & $36-51$ & 0 & 0 \\
Strongly & $20-35$ & 0 & 0 \\
unmotivated & & & \\
\hline Total & & 30 & 100 \\
\hline
\end{tabular}

The data analysis on the table 3 showed that none of the students responded in negative statement toward the use of mind mapping. There were $13(43.3 \%)$ of students strongly motivated, then 17 $(56.7 \%)$ of students who were motivated. Based on the score of the students in questionnaires, it was found that the highest score was 92 which were categorized as strongly motivated. And the lowest score was 70 which was categorized motivated and most of the students indicated strongly agree and agree as positive statement about the use of mind mapping in learning writing. Then, it could be concluded that the use of mind mapping is able to motivate the students in writing.

\section{Discussion}

The discussion part reveals the findings interpretation related to the students' motivation in learning English through Mind Mapping. This part deals with the interpretation of the findings and the explanation of the research looks like.
The questionnaire consisted of 20 items. There were 10 positive statements and 10 negative statements. The questionnaire showed that most of the students chose alternative answer "strongly agree" or "agree" for positive statements and "disagree" or "strongly disagree" for the negative statements. From the data of interview, Paradifa as a second semester students of Tomakaka University states that "Mind Mapping is very good because this method helps students to note down the most important information by using key words and it makes easier to write". So, from the previous result, it is concluded that most of the students are happy and find it easier to writing using mind mapping method. It indicates that all the students are motivated in learning English through Mind Mapping.

Related to the theories and previous related research findings, one who was stated by Sapitri (2019) that mind mapping not only makes students interested in teaching and learning process but also gives their motivation in writing. It can be concluded that this research obviously supports the previous findings, which explain that applying Mind Mapping, where the students write based on the ideas found from map they make, is able to motivate the students in writing. Mind mapping does not only provoke the students' ideas in writing but students become selfunderstanding of what they are going to write, it makes them more motivated to finish their writing. As Hidi (2006) defines, "Writing is not only a process of making meaning but also an activity through which individuals engage in self-understanding".

From the discussion above, it can be concluded that the second semester students of Tomakaka University of Mamuju are motivated in writing through Mind Mapping. Since all of the indicators of motivation in learning were completely done. 


\section{Conclusion}

Based on the findings and discussion in the previous chapter, the researcher concluded that the second semester students of Tomakaka University of Mamuju are motivated in writing through Mind Mapping method. It can be shown from the data of writing test, questionnaire and interview.

The result of the treatment given showed a trend of increasing students' writing score. There were also a significant improvement of the students' pretest and posttest grade. Other data are students' positive responses to the questionnaire distributed where most students gave answers that Mind Mapping method was very useful in increasing their writing motivation. As supporting data, in the interviews conducted, students said the same that Mind Mapping was able to drastically raise their writing motivation, especially in finding ideas.

\section{References}

[1] Ali, S. M. 2015. The effects of Problembased learning to Writing Achievement of the tenth graders of SMAN 1 Enrekang. Thesis. Unpublished FPBS UNM. Makassar.

[2] Al Kamli,H. M. (2018). The Effect of Using Mind Maps to Enhance EFL Learners' Writing Achievement and Students' Attitudes Towards Writing at Taif University. (Master Thesis). Retrieved from Arab World English Journal (ID Number: 232. April 2019, 1-92. DOI: https://dx.doi.org/10.24093/awej/th.232, Accessed on August 15th 2019.

[3] Buzan, Tony. http://www.usingmindmaps.com/what-is-amind-map.htmlAccessed on August $13^{\text {th }}$, 2019.

[4] Depdiknas. 2008. Kurikulum 2006: StandarKompetensi SMK/MA. Jakarta: DarmaBakti.
[5] Hidi, S., \&Boscolo, P. (2006). Motivation and writing. Handbook of writing research, 144(157), 304-310.

[6] Megawati, F., \&Anugerahwati, M. (2012). Comic Strips: A Study on the Teaching of Writing Narrative Texts to Indonesian EFL Students. TEFLIN Journal, 23(2), 183-205. doi:http://dx.doi.org/10.15639/teflinjournal. v23i2/183-205

[7] Sahardin, R. Hanun, C.S, \&Gani, S.A., 2017. Using Think-Pair-Share for Descriptive Texts. http://www.jurnal.unsyiah.ac.id/SiELE/artic le/view/7004/5746. Accessed on July 7, 2020.

https://doi.org/10.24815/siele.v4i1.7004.

[8] Sapitri, L., Rachmawati, E., \&Surachmat, A. M. (2019). The Use of Mind Mapping Technique to Increase EFL Students' Motivation in Writing (A Case Study at the Eighth Grade of A Junior High School in Brebes). Journal of English Education and Teaching, 3(3), 392-402.

[9] Sugiyono. 2016. MetodePenelitianPendidikan (PendekatanKuantitatif, $R \& D)$. Bandung: Alfabeta.

Kualitatifdan

\section{Writers' Profile}

NurulHasanah, S.Pd., M.Pd. graduated from S-1 and S-2 in English Education at the State University of Makassar in 2013 and 2015. Then she has been taught the disciplines as a lecturer at TomakakaMamuju University since 2016. The author is active as a member of ADRI (Expert and Lecturer of the Republic of Indonesia) part of West Sulawesi. 